\title{
A Study on the Influence of the Bhagavat Gita on Modern day Corporate Stress Management
}

By Saptarsi Ganguly \& Mriganka Gope

Abstract- The Bhagavat Gita is a prehistoric Hindu Holy book that was concocted eras before the modern pillars of business management was reputable. The book is believed to have huge potentials to capture reader's devotion through its allegorical testimonials on human life and the ways to eradicate sufferings and distortions from the same. Today's modern corporate world is witnessing a huge anguish in the form of employee stress. Recent studies have established the fact how an employee's mental stress has become his principal adversary on the work. Business juggernauts are spending millions for the mental stability and satisfaction of their employees but the phenomenon has become too disquieting to be neglected any further. The concerned research article attempted to find whether the age old Hindu Holy book has anything to do with the employee stress management of today. The study has probed deep into the wisdoms of the specific chapters of the book and the implications of the same on the average employee of the $21^{\text {st }}$ century.

Keywords: bhagavat gita, employee stress, business management, corporate world, business juggernauts.

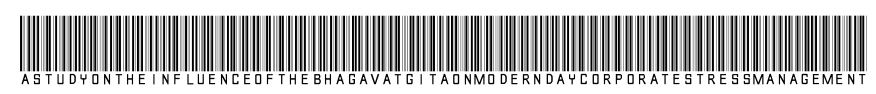

Strictly as per the compliance and regulations of:

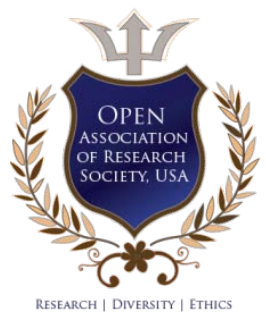

(C) 2020. Saptarsi Ganguly \& Mriganka Gope. This is a research/review paper, distributed under the terms of the Creative Commons Attribution-Noncommercial 3.0 Unported License http://creativecommons.org/licenses/by-nc/3.0/), permitting all noncommercial use, distribution, and reproduction in any medium, provided the original work is properly cited. 


\title{
A Study on the Influence of the Bhagavat Gita on Modern day Corporate Stress Management
}

\author{
Saptarsi Ganguly ${ }^{\alpha} \&$ Mriganka Gope ${ }^{\sigma}$
}

Abstract-The Bhagavat Gita is a prehistoric Hindu Holy book that was concocted eras before the modern pillars of business management was reputable. The book is believed to have huge potentials to capture reader's devotion through its allegorical testimonials on human life and the ways to eradicate sufferings and distortions from the same. Today's modern corporate world is witnessing a huge anguish in the form of employee stress. Recent studies have established the fact how an employee's mental stress has become his principal adversary on the work. Business juggernauts are spending millions for the mental stability and satisfaction of their employees but the phenomenon has become too disquieting to be neglected any further. The concerned research article attempted to find whether the age old Hindu Holy book has anything to do with the employee stress management of today. The study has probed deep into the wisdoms of the specific chapters of the book and the implications of the same on the average employee of the $21^{\text {st }}$ century. The study has also gabbed about the major reasons behind such atrocities in the corporate world and has also provided data, primary as well as secondary to back-up its hypothesis.

Keywords: bhagavat gita, employee stress, business management, corporate world, business juggernauts.

\section{INTRODUCTION}

T he business world has never been more viable than what it is today. The corporate world has been fronting several hitches in the forms of low productivity, low employee morale, lack of motivation, unfitting leadership skills and so on. However, there has been a recent phenomenon in the field of business management that shows that corporate employees are showing symptoms of high level of work stress which is leading to several mental as well as physical predicaments resulting in high labor turnovers and deficiency in the overall yield of the concerned workforces (Sharma \& Shakir, 2017, p. 657). In this regard this research paper aims at concentrating on the root causes of such mental trouble of the employees in the corporate world as well as voicing a way-out from the same with the help of an ancient Hindu religious text, The Bhagavat Gita. The Bhagavat Gita is said to have solutions to all problems of mankind. It is a part of the longest poem in the human civilization, Mahabharata, a Hindu epic.

Author a: Junior Research Fellow, Department of Commerce, University of Calcutta.

Authoe o: State Aided College Teacher, Umeschandra College. e-mail: princerishi.070@gmail.com
The chapter 6 of the Holy book is said to have an expedient approach towards the rudimentary problem that the folks from the corporate world is facing and that is excessive mental stress and severe anxiety on the work place (Mukherjee, 2017). In this regard it has to be kept in mind that the concerned research paper deals with the idea of the influence that the Bhagavat Gita has on the modern day business management in regards to handling employee's psychological stress and unease on the job. The Gita is a Hindu holy scripture that consists of 700 shlokas or verses (Chopra et al., 2018, p. 28). It has been divided into 18 chapters. It is a detailed dialogue based conversation between two main characters of the epic, Arjuna and Krishna.

The background of the conversation is on the combat zone of Kurukshetra before a fear-some battle. Arjuna, who has been terrified at the thought of having to kill his own family in order to triumph the war, falls into severe anxiety and Krishna counsels him through his divine message. It is regarded as a 48 minute conversation that was penned down by Vyasa, the great sage, for the relief of mankind in future against mental dilemma. As per certain scholars the Bhagavat Gita was composed sometimes in the early days of $200 \mathrm{BC}$ which is approximately 2200 years from now (Mukherjee, 2017). The mere thought of a 2200 year old book having possessions on the business scenario today itself is quite astonishing.

\section{a) Research Objectives}

The concerned research paper aims to achieve the following objectives:

- To acquire a bird's eye view on the delinquent of employee stress management in the modern corporate world.

- To delve deep into the antiquity of the Hindu Holy Book the Bhagavat Gita

- To designate the knowledges of the Holy Book in brief.

- To acme the recent statistics correlated to employee stress in the corporate world.

- To ascertain elucidations to the trouble of employee's mental stress from the Bhagavat Gita.

- To ripen a hypothesis on the dependence of employee success over Self-restraint and ethical consciousness. 


\section{b) Rationale of the Research}

The work related stress and pressure is surmounting among the employees at the current juncture. A large percentage of the entire working population is facing enormous mental as well as physical stress owing to several major reasons (Sharma \& Shakir, 2017, p. 657). Hence, there is a need to delve deeper into the concerned issue for finding out the strategies meant for resolving the identified problem.

\section{il. Review of Literature}

Several researchers across the globe have been trying to decode the propositions of the Bhagavat Gita since quite a time now. Not only in the realms of India but also in the west, have great intellectuals and eminent personalities been effected with the wisdoms of the concerned Holy book (Mukherjee, 2017). For instance Julius Robert Openheimer, the father of the atomic bomb, was highly interested and deeply gratified by the teachings of the Bhagavat Gita (Yadav et al., 2017, p. 91). It is so said, that he often gifted the book to others and suggested them to have a read of the same. The entire world has also witnessed the genius quote from the Holy book after the atomic explosions at Hiroshima and Nagasaki. Here are the axioms of few researchers on the stimulus of Bhagavat Gita on the modern day principles of business management.

According to Pillai, Agarwal \& Pillai (2019), the Indian thought and education structure has similar traits from that of the western world. The country however is unaware of the rich cultural and religious legacy that it beholds. As per the study, there are generally two types of awareness that is conveyed in the Bhagavat Gita, one being physical while the other being psychic. The researchers have stressed on the prerequisite of the teachings of the Bhagavat Gita in building an individual's moral charm. The study has also delved deep into the history of modern day business management. It states that the all-inclusive philosophies of business management were first erected in the early years of the $20^{\text {th }}$ century. There have been references of eminent personalities in the field of management like, Alexander Church, Henry Fayol, Elton Mayo and so on. The study has emphasized the correlation between the principles of management and the teachings of the Bhagavat Gita. It has specifically mentioned the chapters and verses of the Book where such principles of management have been emphasized. The research paper has underlined the principles that have been proposed by the father of management Henry Fayol and have endeavored to find similar teachings in the Bhagavat Gita (Mukherjee, 2017). It has predominantly focused on the principles of leadership, discipline, motivation and authority and responsibility. The research paper on the other hand, has fixated on the chapter 3, 6 and 2 of the Holy book. It anticipated to have found exquisite similarities between the principles of management and the teachings in the Holy book. The study states that in the verse 20-21 of the chapter 3 of the book Krishna talks about leadership qualities and how to mature the same in oneself. Similar mannerisms have also been highlighted regarding chapter 6 and 2 of the Holy book.

According to Anila \& Krishnaveni (2017), the Bhagavat Gita is the greatest treasure to the entire world. The lessons of the Holy book contain enough knacks to develop mind managing capabilities in any human being. The major toil that the corporate world is fronting today is the extreme mental hassle and work related anxiety. An organization has to suffer in terms of profitability as well as high labor turnover (Mukherjee, 2017). The extreme stress that an average employee faces could be the result of high cut-throat antagonism in the business scenario. The study also talks about the mentality of most Indians regarding the inferiority of anything Indian to its Western counterpart. The study states that each and every work requires a sound human mind to perform the work in a proper manner (Mukherjee, 2017). This human mind as far as men involved in the business consequence are concerned in most cases, is no more sound due to several corporate hitches. The study has decoded certain principles of the Bhagavat Gita. These principles are extremely relevant in the modern day business management as it more or less nullifies the present problem of employee stress and the struggles of business managers to deal with the same. Few of such principles can be elaborated in brief.

The first principle that the study talks about is the efficiency of undertaking stuffs dead-on. An individual must know how to do the correct thing at the correct place and at the correct time. The next major principle of the Bhagavat Gita is to work without considering the consequences (Mukherjee, 2017). An individual who is inclined to look after any work without attaching himself to the fruits of the same can achieve success and accomplish mental peace at the same time. There are various other principles that the study has talked of. The study has also tinted the teachings of the Holy book to resolve organizational conflicts with ease. The context of the Bhagavat Gita is considered to be allegorical in nature. Though the teachings have been spoken in a war environment nearly 2200 years ago, it is still relevant and can be used in multiple branches of human troubles and dilemma including business management.

According to Acharya (2015), decision making is the core assignment of any managerial personnel. To make the precise decision at the exact time without giving in to moral dilemmas is the main standard of business management. The study debates about the age old Bhagavat Gita and its commentary on the human mind and means to control the same. The study emphasizes on the history of the book and its 
impression on the modern day business arena. It also mentions that the dialogue form of communication is used in the book which makes the message clearer and more direct towards the audience (Mohajan, 2018, p. 28). The researcher also talks about the meaning and forms of yoga that one needs to perform as per the book to grab control on the mind, which, otherwise can cause havoc to one's mental peace and no work could be accomplished in the veracious method.

The Bhagavat Gita states that the mind can be a great friend or a great foe to an individual depending upon how he indulgences the same. The paper also talks about non attachment towards the result of any work and concentrating on the work itself for a better productivity and contented lifecycle. The paper also opines that personality management is the apex function in the business arena and it overpowers most other branches of business management such as reserve, cash and wealth management (Mohajan, 2018, p. 28). The researcher further articulates that most of the Indians are well aware of the fundamental teachings of the Bhagavat Gita whether they have gone through the same or not. As the Holy Bible is to the Western society, the Holy Bhagavat Gita is to the Indian fraternity. The researcher concluded with the statement that the Bhagavat Gita is still very much relevant in all fields of human occupations including business management.

\section{ReseArCh Methodology}

In the contemporary years, corporate stress has developed a major exertion in the realms of business and many have succumbed to the same. It is worth noting that the stress that an individual employee goes through, not only impressions his or her state of mind but also his or her overall work yield and organizational target achieving aptitude. The concerned study endeavors to rejoinder the question, whether the Indian Holy book, the Bhagavat Gita has any influence over the modern day corporate stress management. The Bhagavat Gita instils how to fetch control of one's mind and operate it to its fullest potential (Mukherjee, 2017). The study uses both primary as well as secondary data on employee stress in recent years. The study implies quantitative research wherein the relationship between the derived data will be ascertained (Mohajan, 2018, p. 28).

The primary data has been collected through survey questionnaire. The concerned research article has implied online method of survey research and comprises of 25 respondents on the primary data aspect of things. The researchers have attempted to develop a null hypothesis that is- $H_{1=>} Y=f\left(X_{i}, X i i\right)$, Here, $Y$ is the dependent variable whereas $X_{i}$ and $X_{i i}$ are the independent variables. $Y$, in this study, represents the success rate of the concerned employees in their respective areas of operation in the recent past whereas
$X_{i}$ and $X_{i i}$ represents self-restraint and ethical conscience of the employees respectively, the two major qualities that have been conveyed in the Bhagavat Gita. It is to be distinguished that the study entails the use of judgmental sampling technique. The statistical package IBM SPSS and Microsoft excel that are meant for research and analysis purposes have been used in the study for the analysis of the collected data (Fletcher, 2017, p. 185).

\section{Findings And Suggestions}

Today's corporate ecosphere has become the epicenter of extreme mental hassle and unease. Most of the people operational in this sector is facing the challenge to keep themselves motivated and at peace to overwhelm the ever increasing tussle in the concerned field. As per current surveys that are being steered across the globe, the United Nations of America has come up with some jaw dropping upshots on employee's mental health on the work. Near about 83\% of the total corporate workforces in the country suffer from some sort of mental stress. The commercial houses lose nearly $\$ 300$ billion per annum in-order to pay for the medical treatments of their employees (Parthasarathi et al., 2017, p. 40). The matter worsens when the surveys suggest that only $43 \%$ of the employed workers think that they are taken care of by their employers or immediate superiors. These data endangers the basic pillars of management timehonored by the so called fathers of modern business management. However, if one goes back in time, the matter was not this serious nearly a decade ago. In the initial days of the $21^{\text {st }}$ century, employee stress levels were not that extraordinary (Mukherjee, 2017). Therefore, it is definitely a matter of great concern that in these 20 years what drastic vagaries might have materialized that the situation is worsening day by day. As per the reports of the European Agency for safety and health at work 2005, there was a decrease in the parameters of work stress at the beginning of the $21^{\text {st }}$ century. 
Table 1: Parameters of Work Stress at the Beginning of the $21^{\text {st }}$ Century

\begin{tabular}{|c|c|c|c|}
\hline Question & 1995 & 2000 & 2005 \\
\hline $\begin{array}{c}\text { Does labor disturb well- } \\
\text { being }\end{array}$ & $57 \%$ & $60 \%$ & $31 \%$ \\
\hline Strain & $28 \%$ & $23 \%$ & $18 \%$ \\
\hline Exhaustion & $20 \%$ & $23 \%$ & $18 \%$ \\
\hline Pains & $13 \%$ & $15 \%$ & $13 \%$ \\
\hline Back pain & $30 \%$ & $33 \%$ & $21 \%$ \\
\hline Impatience & $11 \%$ & $11 \%$ & $10 \%$ \\
\hline Anxiety & $7 \%$ & $7 \%$ & $9 \%$ \\
\hline
\end{tabular}

Source: (European Risk Observatory Report, 2005)

As per the above cited table is concerned, the data austerely designates towards a decline in the parameters of work related stress in the European union in the early years of the $21^{\text {st }}$ century. However, recent reports on the same would voice otherwise. In the early months of 2018, two eminent employee assistance providers to Indian organizations shepherded a survey on employee stress management, and the results were deplorable (Mukherjee, 2017). The two leading employee assistance providers, Optum and Itolhelp.net found that among 8 lakh employees across the country almost half were travailing from some sort of mental agony or stress related to their respective work (Mehta et al., 2018, p. 118). The results, although shocking, could not be unkempt as the survey comprised of around 70 large corporations of the nation.

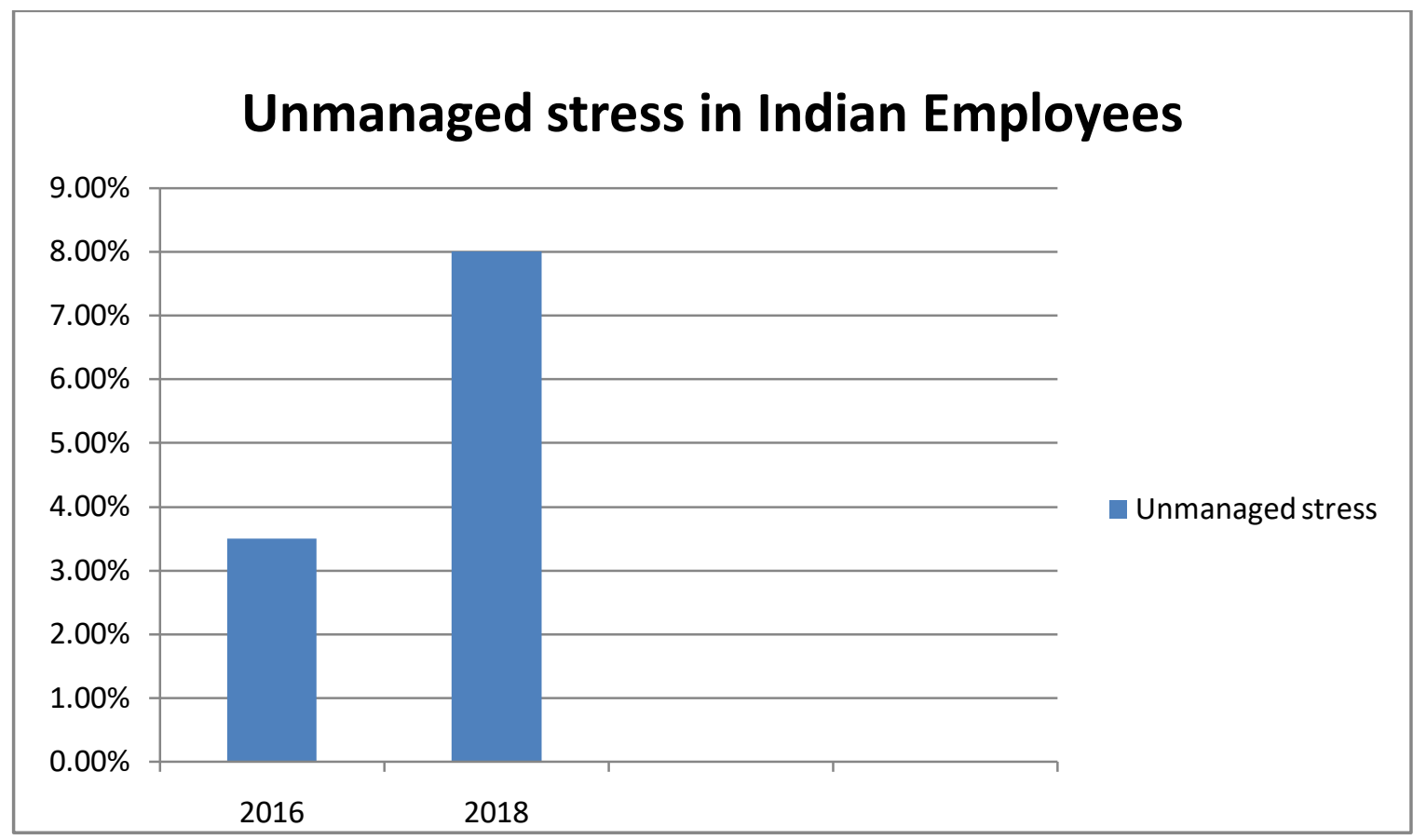

(Source: The Economic Times, 2018)

Figure 1: Unmanaged Stress of Employees in India

As per a survey of The Economic Times, in 2018 near about $8 \%$ of the corporate employees of India has confronted such a high levels of mental stress that they have developed mental sickness (Basu, 2019, p. 22). This figure was nearly half just a couple of years ago in 2016 (The Economic Times, 2018).

According to the World Health Organization, the corporate world across the globe mislays around $\$ 1$ trillion per year on the treatment of their stressed out employees so that their drudgery is not hampered and the organizational cycle remains unhindered (Mehta et al., 2018, p. 118). 


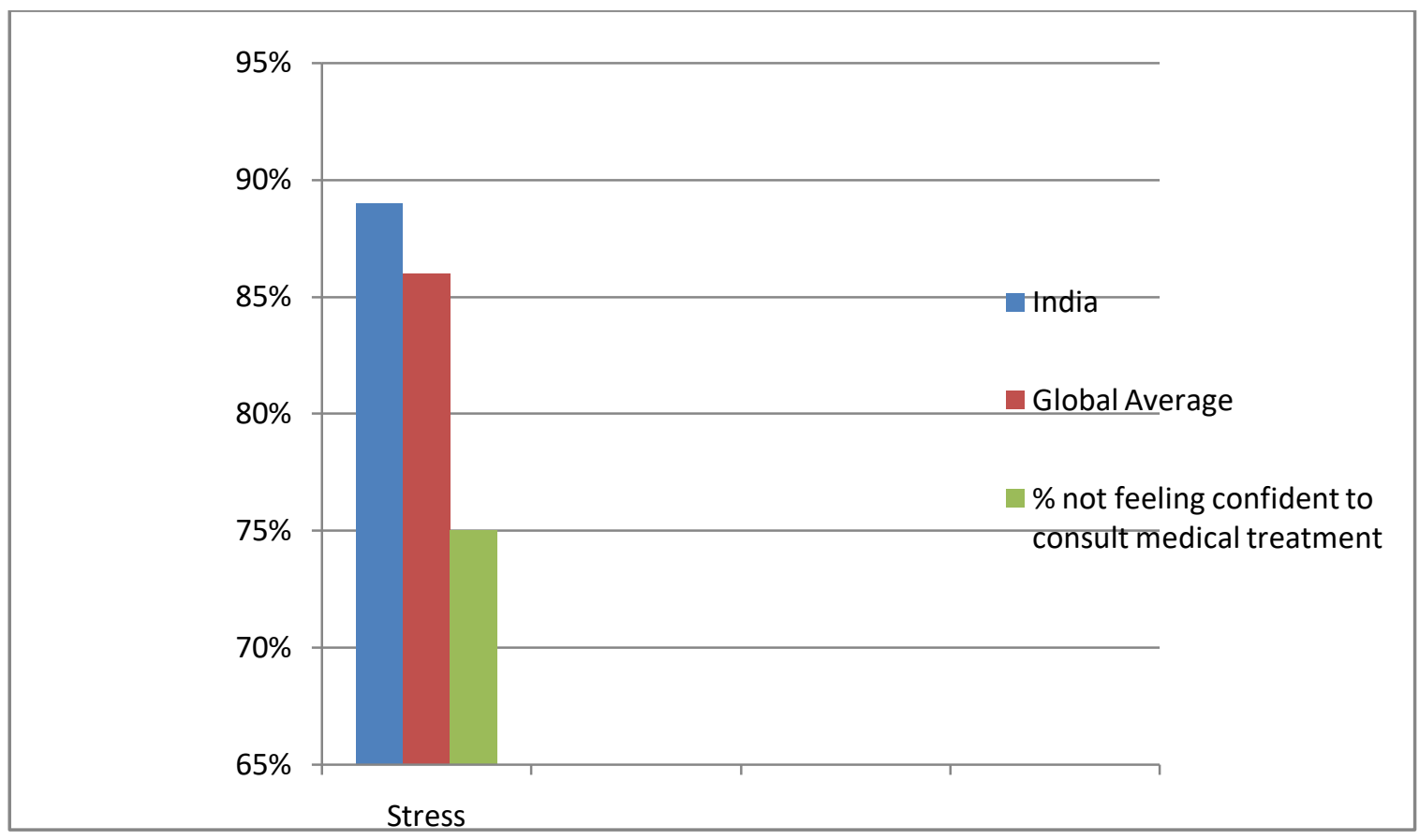

(Source: The Economic Times, 2018)

Figure 2: Percentage of Corporate Personnel having stress in India

According to a recent survey conducted by The Economic Times, it has been perceived that around 89\% of the employees working in the corporate sector in India are suffering from symptoms of mental stress and hyper tension (Basu, 2019, p. 21). It has to be kept in mind that the global mean in this regard in around $86 \%$ (The Economic Times, 2018). The survey further suggests that out of this $89 \%$, nearly around $75 \%$ hesitate to consult a medical expert on the matter (Sardana, 2018, p. 41).

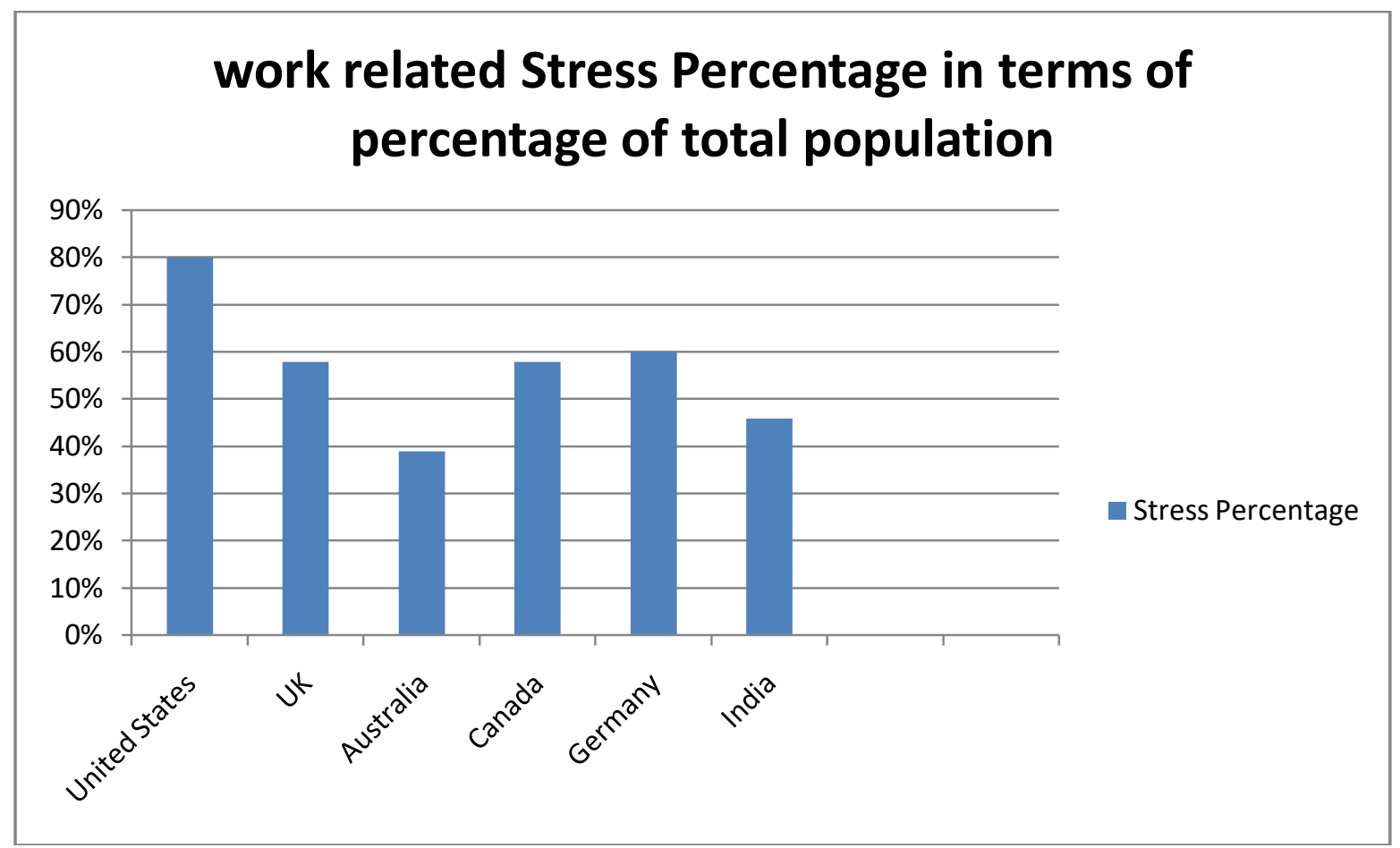

(Source: Harish Saras, 2020)

Figure 3: Work Related Stress Percentage 
The above mentioned graphical representation shows how India fairs in terms of overall stress without keeping in concern, work as the only cause of hassle. The data clearly displays that near about $46 \%$ of the Indian population irrespective of their employment status has shown indications of stress (Mehta et al., 2018, p. 118). However the results are even more appalling if other countries such as the United States and Canada are taken into consideration.

As per certain eminent scholars, the chapter VI of the Bhagavat Gita has a cook-book approach towards the regulation of the mind (Munoz et al., 2020, p. 221). In this book, one may discover the utmost elucidation to the delinquent of the hour. The book sheds light on all minutiae that are to be well-thoughtout in order to control the mind. It statuses, that the mind is the prevalent comrade of human being if properly controlled otherwise can become the supreme foe of the same. In verse 4 of the chapter VI of the book, Krishna, the divine one, says that, one who performs all the errands without paying heed to the fruits or result of the same can lead a life of a yogi thereby not giving in to worldly pleasures and the consequence related stress of the labor (Sailaja \& de Souza, 2017). The book has also focused on Yoga, it states how much to eat as well as how to sleep and meditate to eradicate stress of all kinds. As per the understanding of the researchers, the book stands on the stakes of selfless service, selfrestraint as well as ethical conscience. The book portrays how beautifully the Lordreliefs the pandava prince Arjuna, who was suffering from deep anxiety and depression on the battlefields of Kurukshetra (Munoz et al., 2020, p. 221). The verse 7 of the chapter exquisitely explains, an individual who has dominated the mind, he or she has already touched the celestial soul and for such an individual, cheerfulness and melancholy, warmth and taciturn, reputation and degradation are nothing but the same. It might be true that it is easier said than done however, the book also states that it is quite difficult to control the mind for an ordinary individual. In order to do so one might need to transform himself into a yogi or the mystic one. A yogi is one, who treats all men equally irrespective of his input whether positive or negative on his life (Munoz et al., 2020, p. 221). The book also offers valuable niceties on how one should meditate to bring his mind under his switch. The individual is directed to clutch his or her physique, neckline and cranium vertical in a straight stance and gaze steadily at the tip of the nose. This, according to some scholars like Kashinath Upadhyaya, has had immense effect on the concentrating capacity of individuals and on the ability to let go infuriating thoughts (Alhat, 2019).

The study has conducted a survey of 25 respondents in-order to ascertain answers to the inquiries regarding employee work stress in the modern corporate world. The results of the survey are nothing less than bewildering.

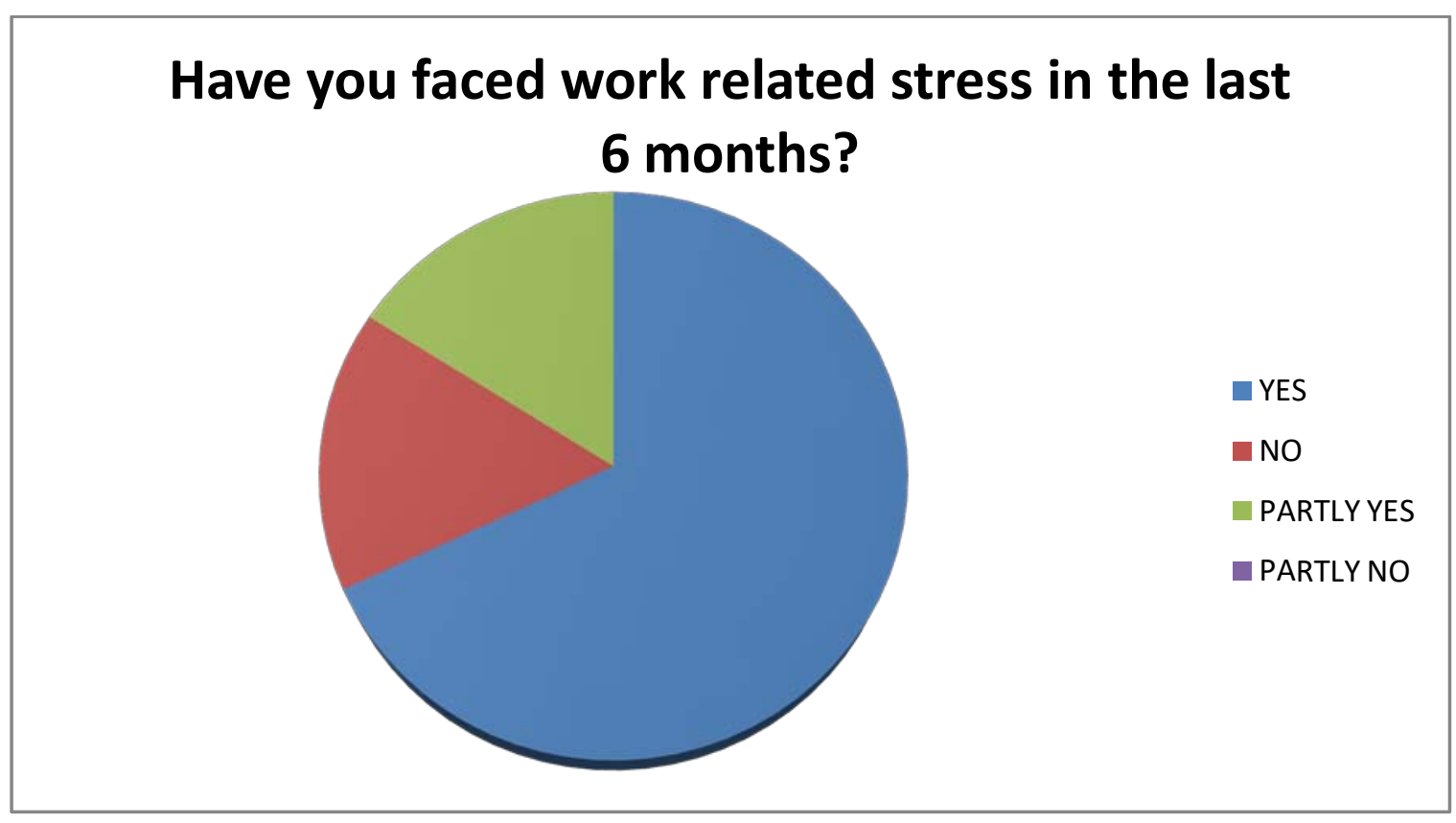

(Source: Author's Creation)

Figure 4: Responses relating to Work Stress

The above mentioned pie chart shows that out of 25 respondents, 17 admitted that they have faced work related stress in the last 6 months. Another 4 respondents said that they were partly affirmative to the phenomenon. Therefore if added, near about $84 \%$ of the 
total respondents has tackled stress related troubles in some form or the other in the last 6 months.

The researchers have also conducted a bivariate regression analysis to prove their hypothesis. The null hypothesis $\left(\mathrm{H}_{0}\right)$ is that the rate of success of an individual respondent is the dependent variable(y) whereas self-restraint $\left(X_{i}\right)$ and Ethical conscience $\left(X_{i i}\right)$ are the two independent variables. Therefore $H_{0}=>y=f$ $\left(X_{i}, X_{i}\right)$. As the details were entered into IBM SPSS and the analysis was performed, the following results have been obtained.

Table 2: Results of Regression Model Summary

\begin{tabular}{|c|c|c|c|c|}
\hline Model & $\mathrm{R}$ & $\mathrm{R}$ Square & $\begin{array}{c}\text { Adjusted } \mathrm{R} \\
\text { Square }\end{array}$ & $\begin{array}{c}\text { Std. Error of the } \\
\text { Estimate }\end{array}$ \\
\hline 1 & $.760^{\mathrm{a}}$ & .577 & .539 & .59868 \\
\hline
\end{tabular}

From the above table it can be found that the $\mathrm{R}$ square value is 0.577 which indicates that there remains a stout relation between the variables and $y$ is exceedingly dependent on $X_{i}$ and $X_{i i}$. However, there also remains a fair amount of standard error of 0.599 which advocates that there is a further opportunity of research on the particular sphere. It is quite evident from the analysis that the success of any individual depends heavily on their individual self-restraint capability and ethical awareness. It is baffling that the age old Holy book: the Bhagavat Gita standpoints on the principles of self-restraint and ethical consciousness and these two factors profoundly affect an individual's accomplishment at work place even after 2200 years of the Book's conception.

\section{Conclusion}

Finally, it can be concluded that the age old Holy book still has applicability in the modern day corporate stress management to a prodigious extent. The basic supports of the Bhagavat Gita, self-restraint and ethical conscience are significant even today and highly upshot the success rate of an average corporate worker. However, there still remains a wide area in this realm to be further combed. The domain itself is extremely vast and dynamic. As per the study, the Bhagavat Gita still holds relevance in the modern age and one can definitely look up to it in order to contest mental stress and work related ethical dilemmas.

\section{References Références Referencias}

1. Alhat, M. S. (2019). Occupational Stress at Workplace: Evaluation of the Corporate Sector in India. Research Journey, 48. https://www.resear chgate.net/profile/Mahendra_Sonawane3/publicatio n/333263556 121 A- English Issue- Stress Man

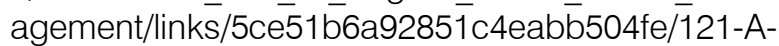
English-Issue-Stress-Management.pdf\#page $=49$

2. Basu, M. (2019). The Essentials of Organizational Management: A Study on the Bhagavad Gita. Management Insight, 15(1), 18-28. DOI: https://doi.org/10.21844/mijia.15.1.3
3. Chopra, K. N., Sharma, N., \& Behura, A. (2018). A Novel Approach for Mathematical Modeling and Theoretical Analysis of Learning Spiritualism for Stress Management for Business Managers in Corporate Sector. Singaporean Journal of Business Economics and Management Studies, 6 (10), 27-37. https://www.singaporeanjbem.com/pdfs/SG_VOL 6 (10)/3.pdf

4. Fletcher, A. J. (2017). Applying critical realism in qualitative research: methodology meets method. International journal of social research methodology, 20(2), 181-194. https://www.research gate.net/profile/Amber_Fletcher/publication/296473 615 Applying_critical_realism in qualitative researc h_Methodology_meets_methöd/inks/5e9ef976299b f13079ae57b2/Applying-critical-realism-in-qualitativ e-research-Methodology-meets-method.pdf https ://www.singaporeanjbem.com/pdfs/SG_VOL_6_(10) /3.pdf

5. Mehta, P., Thakur, A. K., Chauhan, I., \& Uprety, N. (2018). A study on the influence of hindu mythological characters on management practices. International Journal of Economic Plants, 5(3), 116-122. https://www.pphouse.org /upload_article/68554073_4_IJEP_August_2018_Me hta_et_al.pdf

6. Mohajan, H. K. (2018). Qualitative research methodology in social sciences and related subjects. Journal of Economic Development, Environment and People, 7(1), 23-48. https://m pra.ub.uni-muenchen.de/85654/1/MPRA_paper_856 54.pdf

7. Mukherjee, S. (2017). Bhagavad Gita: The key source of modern management. Asian $J$. Management, 8(1).https://d1wqtxts1xzle7.cloudfront .net/53974066/AJM-406----01-10-2016DE_evised12-12-2016 1.pdf?1501003668=\&response-cont ent-disposition=inline\%3B + filename\%3DBhagavad Gita The Key_Source_of Modern_M.pdf\&Expires $=1600513609 \&$ Signature $=$ Rc2azc $\bar{U} d w 6 w 8 i Y m R j K e$ olw0llGi33dRR34pzibgOTJ5mm1jgZuhwbCYyWBLO sHnqktLo1pnPbp9APJHnOfniZeU3zXQyoEgrVVRYrJ a4V5zvnqim1B3x8BsPEr3LI62kp2a4vW46spOLniuy 
TZA16Fg1qdHOd83IJquqOt17GhIrdRzE7NTGnYzYu Q3S1NUb3AYIIWUedSMTwDii6DZ6Jaqq6WT8MD2 dmtygF8y MMPsKKvWSh6sMr9E ViZjTrYqOnmN baeFgmrtz0k3hRb6MXJQoX6IUGfh5ItSLPRJDCilfBT qPGppOWGil9zsaSsP7YpPbLdMpuhZhUS6g_\&Ke y-Pair-Id=APKAJLOHF5GGSLRBV4ZA

8. Munoz, C., Panzitta, A., Rugue, J., Oliveira, D., \& Paz, M. (2020). Suddha Dharma Mandalam Bhagavad Geeta: The Aryan Philosophy Current Today. Open Journal of Philosophy, 10(2), 220-233. https://www.scirp.org/pdf/ojpp_2020051515204726. pdf

9. Parthasarathi, S. K., Reddy, P. N., \& Rao, K. V. S. (2017). Workplace Spirituality Contained in Bhagavad Gita and its Contribution to Work Improvement: A Fundamental to Total Quality Management (TQM). Journal of Management Research, 17(1), 32-46. https://www.researchgat e.net/profile/Srinidhi_K_Parthasarathi/publication/32 7965959_Workplace_Spirituality_Contained_in_Bha gavad_Gita_and_its_Contribution_to_Work_Improve ment_A_Fundamental_to_Total_Quality_Manageme

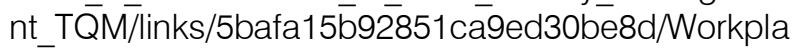
ce-Spirituality-Contained-in-Bhagavad-Gita-and-itsContribution-to-Work-Improvement-A-Fundamentalto-Total-Quality-Management-TQM.pdf

10. Sailaja, R., \& de Souza, R. (2017).Emotional Intelligence, Stress and Coping Styles of Nursing Staff in Corporate Hospitals. Triannual Journal, 41. https://www.researchgate.net/profile/Farzana Begu m3/publication/342871894_Internet_Addiction_The Underlying_Causes_and_Effects_A_Perspective_St ud/links/5f09f77045851550509c9cd4/Internet-Addic tion-The-Underlying-Causes-and-Effects-A-Perspe ctive-Stud.pdf\#page $=5$

11. Saras, H. (2020). Shocking Statistics of Workplace Stress You Never Knew. https://www.harish saras.com/stress-management/shocking-statistics of-workplace-stress/

12. Sardana, A. (2018). An Analytical Introspection of Work Related Stress; In Indian Corporate Sector. Global Journal of Enterprise Information System, 10(2), 36-44. DOI: 10.18311/gjeis/2018 /20930

13. Sharma, S., \& Shakir, M. (2017). Stress management among teachers: The Bhagavad Gita's approach. Educational Quest-An International Journal of Education and Applied Social Sciences, 8(3), 649-658. https://www.research gate.net/profile/Sonal_Sharma22/publication/32163 846_Stress_Management_among_Teachers_TheBh agavad_Gita\%27s_Approach/links/5ac7ab4faca272 abdc5cf646/Stress-Management-among-TeachersThe-Bhagavad-Gitas-Approach.pdf

14. The Economic Times. (2018). 89 per cent of India's population suffering from stress; most don't feel comfortable talking to medical professionals. https://economictimes.indiatimes.com/magazines/p anache/89-per-cent-of-indias-population-suffering-fr om-stress-most-dont-feel-comfortable-talking-to-me dical-professionals/articleshow/64926633.cms

15. Yadav, S., Kohli, N., \& Yadav, A. K. (2017). Organizational Effectiveness through the Lessons of Bhagwat Gita. The International Journal of Indian Psychology, 4(4), 89-95. https://ww w.researchgate.net/profile/Shreshtha Yadav/publica tion/324218025_Organizational Effectiveness throu gh_the_Lessons_of_Bhagwat_Ḡita/links/5ac58̄7d0a 6fdcc051daf2aa0/Organizational-Effectiveness-throu gh-the-Lessons-of-Bhagwat-Gita.pdf 


\section{APPENDIX}

A study on the influence of the Bhagavat Gita on modern-day corporate stress management.

Questionnaire
A. Demographic Questions
Q1. Name of the respondent
Q2. Name of the Department
Q3. Name of the Designation
Q4. Age (in years)
Q5. Gender
Q6. Total Experience (in years)?

Q7. Highest attained qualification

B. Questions to ascertain the rate of success of the employees

Q1. Have you achieved the organizational targets at your work-place in the last 6 months?

Yes

No

Partly Yes

Partly No

Q2. Have you been recognized as the employee of the month in the past 6 months?

Yes

No

Partly Yes

Partly No

Q3. Have you been promoted in the last 6 months for at-least once?

YES

No

Partly YES

Partly No

Q4. Have you been appreciated by your immediate supervisor in the last 6 months?

YES

NO

Partly Yes

Partly No

C. Questions to ascertain the level of Self-Restraint the respondents have

Q1.Have you faced any conflict with your fellow employee in the last 6 months?

YES

No

Partly YES

Partly No

Q2.Do you think it is absolutely necessary to be vocal about your grievances to your immediate supervisor?

YES

No

Partly YES

Partly No

Q3. Have you faced any work related stress in the last 6 months?

YES

No

Partly YES

Partly No

Q4. Has stress affected your physical health and work productivity?

YES

No

Partly YES

Partly No 
Q5. Do you consult the Bhagavat Gita or any other Holy book in times of trouble to seek inner peace?

YES

No

Partly YES

Partly No

Q6. Do you think that the Bhagavat Gita has any relevance in the modern day corporate stress management?

YES

No

Partly YES

Partly No

D. Questions to ascertain the amount of Ethical consciousness the respondents possess.

Q1. Will you be vocal against any injustice meted out to your fellow employee even if it hampers your own position in the organization?

62 No

YES

Partly YES

Partly No

Q2. Do you think it is always necessary to be ethical at your work place?

YES

No

Partly YES

Partly No

Q3. Have you faced any ethical dilemma at your work place?

YES

No

Partly YES

Partly No

Q4. Do you think you have the ability to combat an ethical dilemma?

YES

No

Partly YES

Partly No

Q5. Are you satisfied with your current work?

YES

No

Partly YES

PartlyNo 